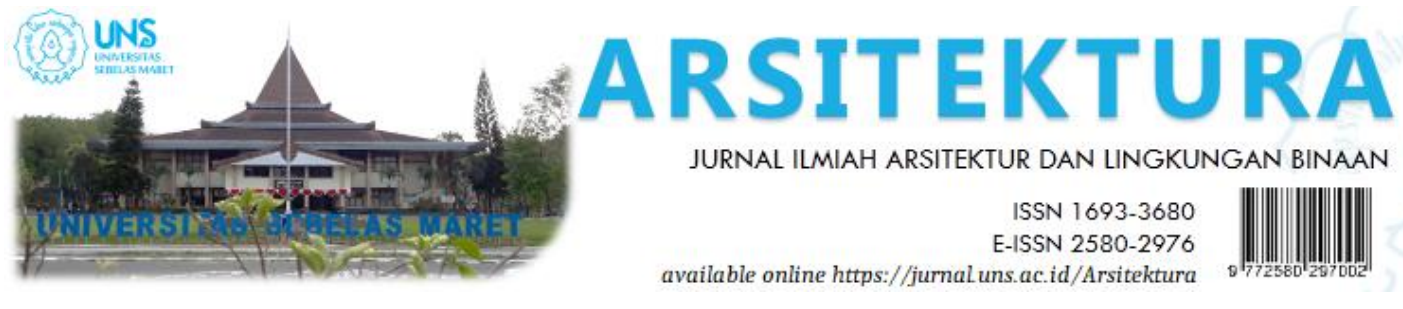

Volume 18 Issue 2 October 2020, pages:361-370

\title{
Identifikasi Potensi Pariwisata Pracimantoro Dari Geopark Hingga Kebudayaan Daerah
}

\section{Identification of Pracimantoro's Potentials for Tourism From Geopark to Local Culture}

\author{
Adira Damai Reforma ${ }^{1 *}$, Ofita Purwani ${ }^{2}$, Tri Yuni Iswati ${ }^{3}$ \\ Department of Architecture, Fa culty of Engineering, Universitas Sebelas Maret ${ }^{1^{*}}$ \\ damai.adira@student.uns.ac.id \\ Department of Architecture, Fa culty of Engineering, Universitas Sebelas Maret ${ }^{2}$ \\ Department of Architecture, Fa culty of Engineering, Universitas Sebelas Maret ${ }^{3}$
}

DOI: https://doi.org/10.20961/arst.v18i2.45273

Received: October 28,2020 Revised:October 30, 2020 Accepted:October 30, 2020 Available online: October 31, 2020

\begin{abstract}
This paperfocuses on identifying tourism potentials ofkecamatan Pracimantoro, Wonogiri. Thisarea has not been recognized as tourist destination despite the fact that some part of the area has been acknowledged as UNESCO's Geopark. While UNESCO encourages the geopark to contribute to the economy of local people, this opportunity has not been realized fully by the people of Pracimantoro. Our research aims to identify Pracimantoro's potentials for tourism so that the result can be used for tourism planning. By compiling potentials found in each village of Pracimantoro, and putting them into categories, we conclude that there are two main potentials for tourism in kecamatan Pracimantoro: Geoparkand culture.
\end{abstract}

Keywords: tourism, geopark, identification, potential, cultural tourism.

\section{PENDAHULUAN}

Kecamatan Pracimantoro merupakan salah satu kecamatan yang terletak di bagian selatan Kabupaten Wonogiri. Kecamatan yang merupakan kecamatan terluas di Kabupaten Wonogiri ini berbatasan dengan Kecamatan Eromoko di bagian utara, Kecamatan Paranggupito di bagian selatan, Provinsi DIY di bagian barat, dan Kecamatan Giritontro di bagian timur (Badan Pusat Statistik Wonogiri, 2019). Kecamatan Pracimantoro terbagi menjadi 18 desa atau kelurahan dengan $72 \%$ lahan yang ada digunakan untuk tanah tegalan, $6 \%$ sawah, $13 \%$ pekarangan, $3 \%$ hutan, dan $6 \%$ untuk lain-lain. Sama seperti daerah lain yang ada di Indonesia, kecamatan ini memiliki iklim tropis dengan rata-rata curah hujan 252,33 $\mathrm{mm} / \mathrm{dt}$ dengan rata-rata 16,67 hari hujan tiap bulan (Badan Pusat Statistik Wonogiri, 2018). Dari segi budaya, Kecamatan Pracimantoro cukup berkembang. Hal ini ditandai dengan cukup banyaknya hasil kebudayaan khas yang ada, seperti makanan tempe theol, jenang grendul, dan sambal cabuk. Selain itu, masyarakat yang ada di Kecamatan Pracimantoro juga menghasilkan berbagai kerajinan, seperti miniatur kayu dan kerajinan pirografi.

Kecamatan Pracimantoro menjadi bagian dari wilayah Gunung Sewu yang telah dikukuhkan 
menjadi UNESCO Global Geopark dalam simposium di Totton City, Jepang, 19 September 2015 (Parno, 2018). Geopark sendiri merupakan suatu kesatuan wilayah geografis yang memiliki signifikansi geologi secara internasional dan dikelola dengan konsep perlindungan, edukasi, dan berkelanjutan. Tujuan dari UNESCO Global Geopark sendiri adalah untuk meningkatkan kesadaran masyarakat akan permasalahan yang dihadapi, seperti penggunaan sumber daya alam secara berkelanjutan, mengurangi efek perubahan iklim, dan mengurangi risiko bencana alam. Selain itu, geopark juga dapat membuka lapangan kerja baru dan meningkatkan perekonomian masyarakat melalui geowisata dengan tetap melindungi sumber daya geologi yang ada di geopark (UNESCO, n.d.).

Selain Gunung Sewu, terdapat 4 Global Geopark lain yang terdapat di Indonesia yaitu

- Gunung Batur

- Geopark Ciletuh Palabuhanratu

- Gunung Rinjani

- Kaldera Toba (Pertiwi, 2020).

Keempat objek wisata tersebut telah berhasil dikembangkan menjadi objek wisata dan telah memberikan dampak positif bagi masyarakat sekitar. Gunung Sewu sendiri telah memberi dampak positif bagi daerah yang dilewatinya, seperti

- Geosite Goa Pindul Gunungkidul

- Geosite Pantai Baron-Kukup-Krakal Gunungkidul

- Geosite Gua Gong Pacitan

- Geosite Pantai Klayar Pacitan

Hal tersebut menunjukkan bahwa Global Geopark yang telah ditetapkan oleh UNESCO memiliki potensi yang sangat besar untuk dikembangkan menjadi objek wisata.

Pengembangan potensi wisata geopark yang ada di Kecamatan Pracimantoro tentunya sejalan dengan tujuan UNESCO dalam meningkatkan kesejahteraan masyarakat. Pengembangan wisata di Kecamatan Pracimanto sendiri masih terhalang oleh belum adanya perencanaan pengembangan wisata yang dilakukan secara terpadu. Untuk dapat melakukan perencanaan pengembangan wisata secara optimal, perlu adanya identifikasi potensi wisata yang ada di Kecamatan Pracimantoro.

\section{METODE}

Penelitian dilakukan dengan cara melakukan kompilasi data potensi yang ada di tiap desa di kecamatan Pracimantoro, kemudian melakukan kategorisasi terhadap data-data tersebut untuk melihat tema wisata apa yang paling dominan. Setelah itu dari tema-tema wisata dominan tersebut diputuskan mana yang paling layak untuk dikembangkan untuk pariwisata dengan melihat potensi dan permasalahan yang ada. Tahapan penelitian divisualkan pada gambar 1 .

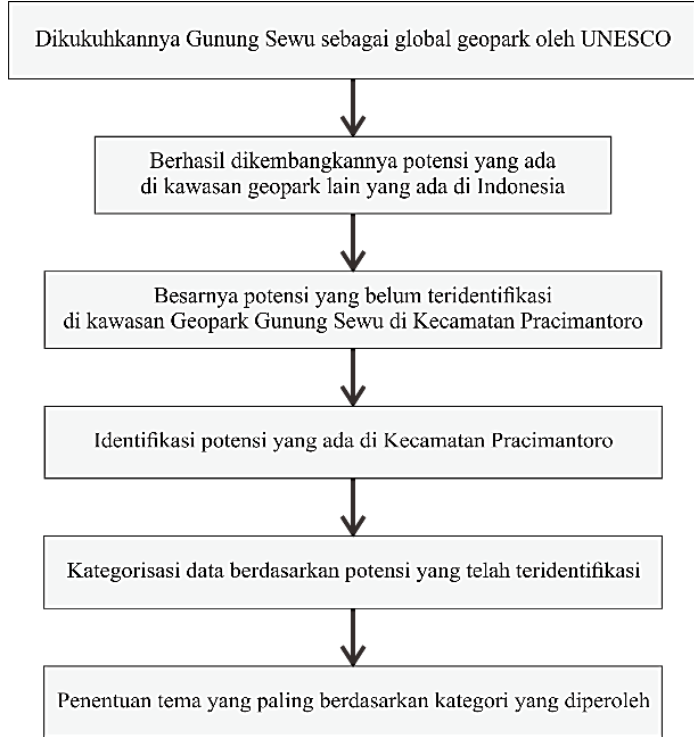

Gambar 1. Skema metode penelitian yang dilakukan dalam penelitian

\section{HASIL DAN PEMBAHASAN}

Kecamatan Pracimantoro merupakan kecamatan yang dilewati oleh jalan nasional rute 3 yang sering disebut dengan jalur pantai selatan dan menghubungkan provinsi Banten, Jawa Barat, Jawa Tengah, DIY, dan Jawa Timur. Jalur ini tentunya memberikan keuntungan bagi Kecamatan Pracimantoro karena dapat dengan mudah dijangkau oleh masyarakat luas. Kecamatan Pracimatoro sendiri terbagi menjadi 18 kelurahan atau desa seperti pada gambar 2, yaitu:

- Banaran

- Gambirmanis

- Gebangharjo 
- Gedong

- Gunggang

- Jimbar

- Joho

- Lebak

- Petirsari

- Pracimantoro

- Sambiroto

- Sedayu

- Suci

- Sumberagung

- Trukan

- Tubokarto

- Watangrejo

- Wonodadi.

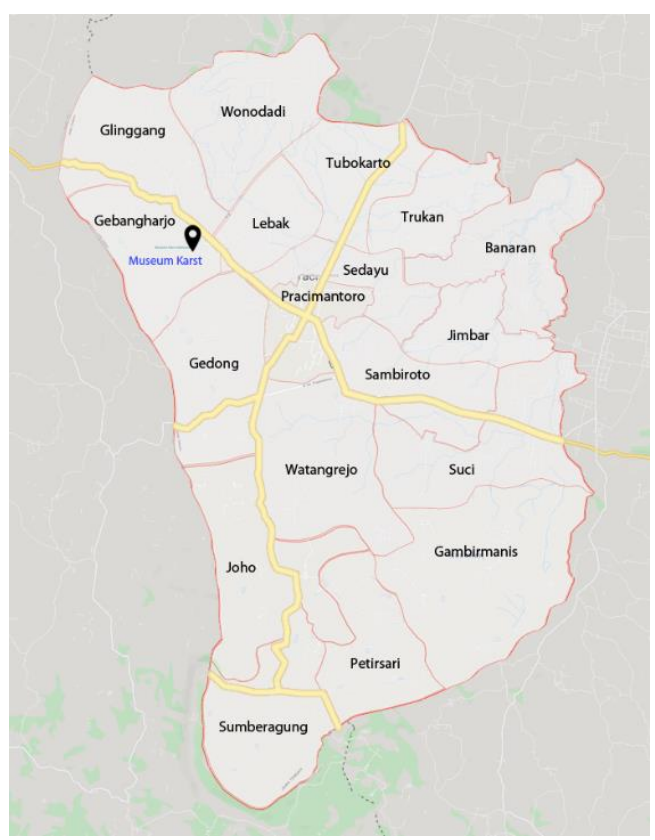

Gambar 2. Peta Lokasi dan batas wilayah desa yang a da di Kecamatan Pra cimantoro, peta dasardarigoogle maps

Kondisi alam dan budaya di daerah Pracimantoro yang berbeda-beda membuat setiap desa yang ada di Kecamatan Pracimantoro memiliki potensi dan keunikan yang beragam.

a. Desa Banaran

Desa Banaran berada di bagian timur laut Kecamatan Pracimantoro. Desa ini terdiri dari 8 dusun dan berbatasan dengan Desa Jimbar, Desa Sedayu, Desa Trukan,
Kecamatan Giriwoyo, Kecamatan Eromoko, dan Kecamatan Giritontro. Di Desa Banaran tidak ditemukan potensi wisata yang dapat dikembangkan ataupun diolah.

b. Desa Gambirmanis

Desa Gambirmanis merupakan salah satu desa yang terletak di bagian tenggara Kecamatan Pracimantoro. Desa ini berjarak $8 \mathrm{~km}$ dari Ibukota Kecamatan Pracimantoro dan memiliki luas sebesar 1.378 ha (Badan Pusat Statistik Wonogiri, 2018). Hal tersebut menjadikan desa ini menjadi desa terluas di Kecamatan Pracimantoro. Desa Gambirmanis memiliki beberapa telaga yang berfungsi sebagai sumber air bersih masyarakat sekitar, antara lain Telaga Sebagor, Telaga Suruhan, dan Telaga Ndoyo.

Salah satu potensi desa yang terbagi menjadi 13 dusun ini adalah bentang alam berupa Lembah Bengawan Solo Purba (Gambar 3). Lembah ini merupakan sisa aliran Sungai Bengawan Solo purba yang mengalir dari Wonogiri menuju Samudera Indonesia dan diperkirakan ada hingga satu juta tahun yang lalu (Parno, 2018).

Kawasan Bengawan Solo purba sendiri sering digunakan untuk beberapa kegiatan olahraga. Salah satunya adalah acara bersepeda yang sejak tahun 2016 diadakan setiap tahun oleh Dinas Kebudayaan, Pariwisata, Pemuda, dan Olahraga Kabupaten Wonogiri (Prasetya, 2018).

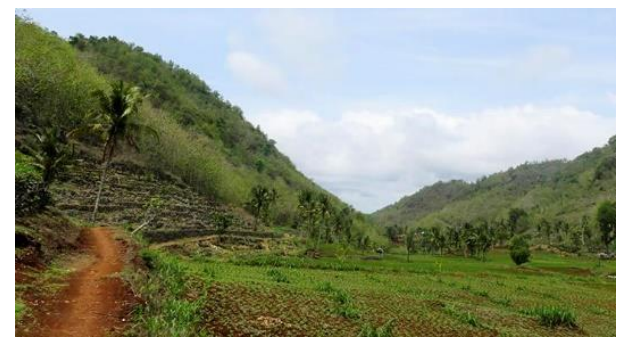

Gambar 3. Kondisi Lembah Bengawan Solo Purba y ang digunakan untuk kegiatan olahraga sepeda oleh Dinas Kebudayaan, Pariwisata, Pemuda, dan Olahraga Kabupaten Wonogiri

Sumber: tra vel.kompas.com/read/2018/11/ 20/070900727/serunya-gowes-susur-lembahbenga wan-solo-purba 
c. Desa Gebangharjo

Desa Gebangharjo merupakan desa yang terletak di bagian barat Kecamatan Pracimantoro. Kecamatan ini dilewati oleh jalan utama yang menghubungkan antara Provinsi Jawa Timur dengan DIY, sehingga akses transportasi menuju desa ini relatif mudah untuk dijangkau. Desa ini memiliki Embung Gebangharjo yang berfungsi untuk pengairan dan kebutuhan masyarakat desa.

Salah satu obyek wisata yang sudah cukup dikenal di desa ini adalah Museum Kars Indonesia, seperti pada gambar 4. Museum ini memamerkan segala sesuatu tentang batuan dan Kawasan karst seperti sejarah geologi, kehidupan prasejarah, dan kehidupan masyarakat modern. Di sekitar museum terdapat 7 situs geopark berupa goa antara lain:

- Goa Mrico

- Goa Tembus

- Goa Sodong

- Goa Sonya Ruri

- Goa Potro Bunder

- Goa Song Gilap

- Goa Luweng Sapen

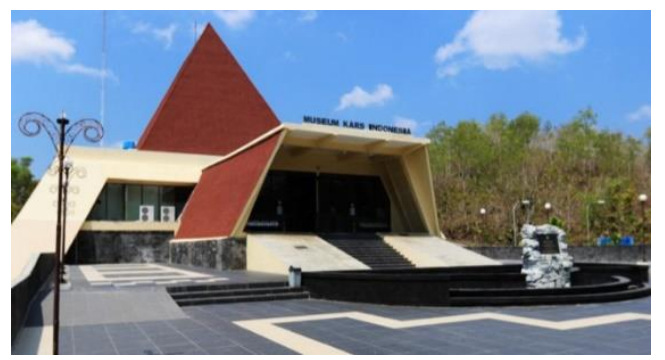

Gambar 4. Bagian depan Museum Kars Indonesia y ang berada diDesa Gebangharjo Sumber:Kementrian Energi dan Sumber Daya Mineral

Selain situs geopark, di desa ini terdapat Pura Puncak Jagad Spiritual yang digunakan untuk upacara adat odalan oleh masyarakat Hindu. Selain itu di Desa Gebangharjo juga terdapat sentra kerajinan blangkon yang hasil kerajinannya telah sampai ke berbagai daerah, lihat gambar 5 .

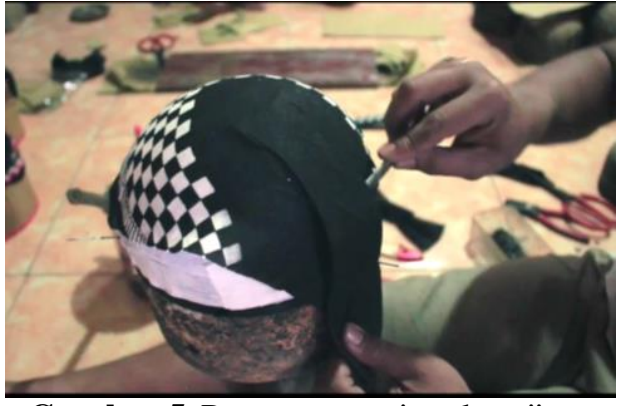

Gambar 5. Proses pengerjaan kerajinan blangkon diDesa Gebangharjo Sumber: Kecamatan Pracimantoro

d. Kelurahan Gedong

Kelurahan Gedong merupakan satusatunya kelurahan yang ada di Kecamatan Pracimantoro. Kelurahan ini terletak tepat di sebelah barat Ibukota Kecamatan Pracimantoro. Lokasi Kelurahan Gedong sangat strategis karena dilewati oleh jalan utama yang menghubungkan Provinsi Jawa Timur dan DIY di bagian utara dan Jalan utama yang menghubungkan Kecamatan Pracimantoro dengan Kabupaten Wonogiri.

Kelurahan Gedong memiliki beberapa telaga yang berfungsi sebagai sumber air masyarakat desa. Selain sebagai sumber air, salah satu telaga yang ada di kelurahan ini telah ditetapkan menjadi obyek wisata, yaitu Telaga Winong pada gambar 6.

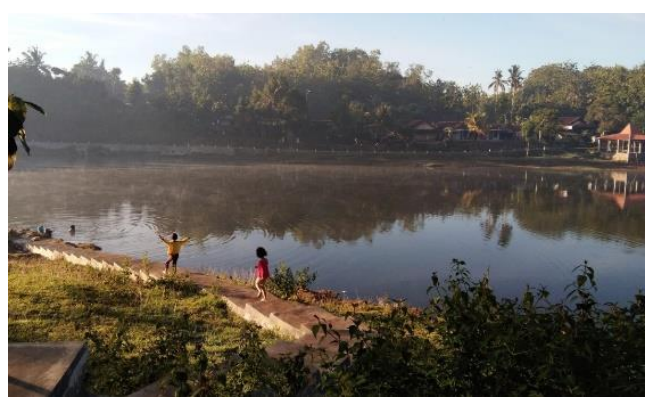

Gambar 6. Anak-anak sedang bermain dan berenang di Telaga Winong Sumber: maps.google.com

e. Desa Glinggang

Desa Glinggang terletak di sebelah barat laut Kecamatan Pracimantoro. Akses utama keluar masuk Desa Glinggang berupa jalan utama yang menghubungkan Provinsi Jawa Timur dan DIY. Desa ini berbatasan dengan Desa Gebangharjo, Desa Wonodadi, Desa Lebak, dan 
Kabupaten Gunung Kidul, DIY. Desa Glinggang memiliki dua potensi geosite berupa goa, yaitu Goa Sambi dan Goa Song Agung (Kabupaten Wonogiri, 2017)

\section{f. Desa Jimbar}

Desa Jimbar berlokasi di bagian timur Kecamatan Pracimantoro dengan jarak 3 $\mathrm{Km}$ dari ibukota kecamatan. Desa Jimbar memiliki sejarah yang cukup Panjang. Desa ini termasuk dalam wilayah Kerajaan Mangkunegaran dan dipimpin oleh orangorang keturunan Mangkunegaran (Desa Jimbar, n.d.).

Dengan luas sebesar $471 \mathrm{Ha}$, desa ini memiliki luas wilayah terkecil kedua jika dibandingkan dengan desa-desa lain yang ada di Kecamatan Pracimantoro. Dengan luas wilayah yang relatif kecil tersebut, masyarakat di desa ini juga melakukan inovasi di bidang pertanian melalui petani muda modern yang berfokus di bidang pertanian hortikultura mulai dari pembibitan hingga distribusi, pada gambar 7. Selain itu, Desa Jimbar juga memiliki Embung Pancuran Sari, yang digunakan untuk pengairan, perikanan, dan pemancingan oleh masyarakat desa.

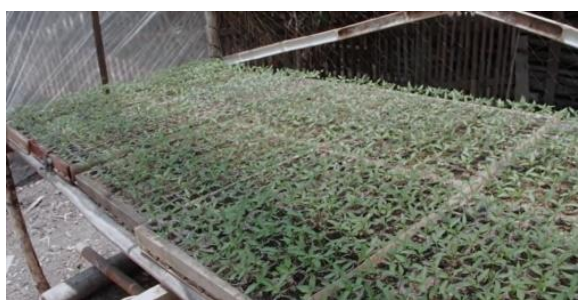

Gambar 7. Kegiatan Pembibitan Hortikultura yang dilakukan oleh paguyuban petani muda modern di Desa Jimbar Sumber: (Prakosa, 2018)

g. Desa Joho

Desa Joho adalah desa yang terletak di bagian selatan Kecamatan Pracimantoro. Desa ini dilewati oleh jalan utama yang menghubungkan Kecamatan Pracimantoro dan Kabupaten Wonogiri sehingga akses keluar masuk desa ini cukup mudah. Salah satu potensi yang ada di desa ini adalah Telaga Kenanga. Sama seperti telaga lain yang ada di Kecamatan Pracimantoro, telaga ini memiliki fungsi utama sebagai pengairan dan dimanfaatkan oleh masyarakat untuk perikanan dan pemancingan masyarakat, seperti pada gambar 8 .

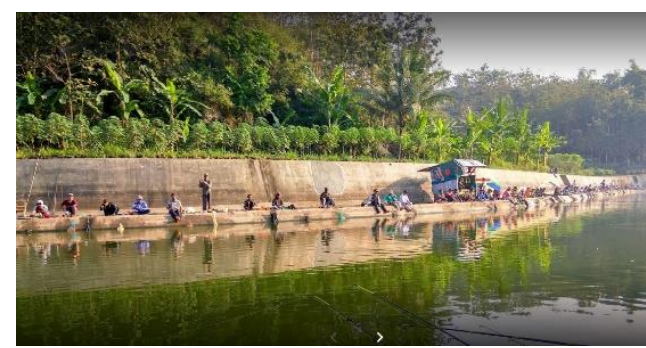

Gambar 8. Masyarakatyang sedang memancing di Telaga Kenanga Sumber:maps.google.com

h. Desa Lebak

Desa Lebak berada tepat di sebelah barat laut ibukota Kecamatan Pracimantoro. Desa yang memiliki luas 483,8 Ha ini dilewati jalan utama yang menghubungkan Provinsi Jawa Timur dan DIY sehingga memiliki lokasi yang strategis.

Sejak tahun 1998, Desa Lebak telah menghasilkan hasil kerajinan berupa handycraft yang berasal dari limbah kayu dan kayu gelondong, lihat gambar 9. Hasil kerajinan yang dihasilkan oleh masyarakat Desa Lebak berupa barang setengah jadi dan didistribusikan ke Klaten dan Prambanan.

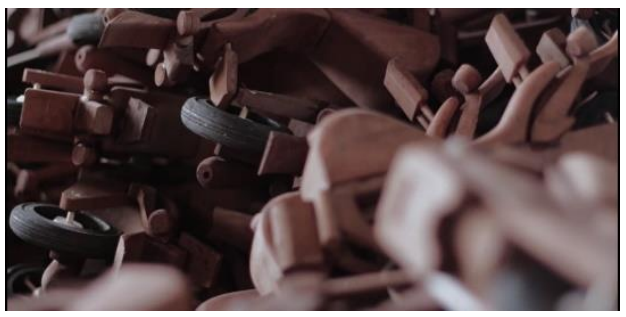

Gambar 9. Hasil Karya Kerajinan Ka yu di Desa Lebak yang berupa barang setengah jadi Sumber:(Prakosa, 2018)

i. Desa Petirsari

Desa Petirsari merupakan salah satu desa yang berada di bagian selatan Kecamatan Pracimantoro. Desa ini berbatasan dengan Desa Sumberagung, Joho, Gambirmanis, dan Watangrejo. Potensi yang ada di Desa Petirsari adalah telaga Braholo. Selain itu, desa ini juga menjadi bagian dari lembah aliran sungai Bengawan Solo purba. 
j. Desa Pracimantoro

Desa Pracimantoro merupakan ibukota Kecamatan Pracimantoro. Lokasi desa yang berada di tengah kecamatan dan menjadi tempat persimpangan dua jalan utama yang ada di Kecamatan Pracimantoro menjadikan desa ini sebagai pusat kegiatan dan pusat perekonomian yang ada di Kecamatan Pracimantoro. Di Desa Pracimantoro juga terdapat Telaga Timbang yang digunakan oleh masyarakat untuk pengairan dan kegiatan memancing. Terminal Pracimantoro yang berada di desa ini merupakan satu-satunya terminal yang ada di Kecamatan Pracimantoro. Terminal ini menghubungkan Kecamatan Pracimantoro dengan daerah lain melalui sarana transportasi bus. Selain terminal, Desa Pracimantoro memiliki pasar umum dan pasar hewan yang menjadi pusat kegiatan ekonomi masyarakat. Sebagai pusat kegiatan ekonomi, banyak ditemukan penjual makanan khas yang ada di Kecamatan Pracimantoro, seperti sate kambing pada gambar 10, sate sapi, tongseng, dan sambal cabuk.

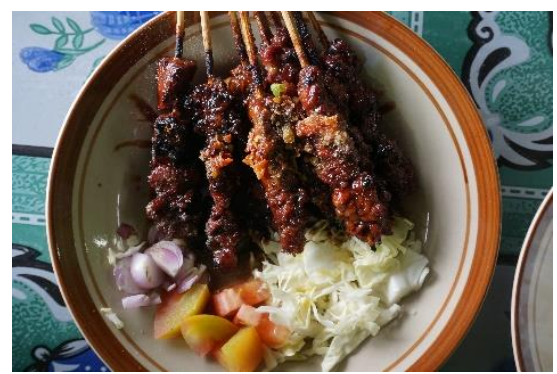

Gambar 10. Sate Kambing Khas Pra cimantoro yang dijual di Terminal Pracimantoro

k. Desa Sambiroto

Desa Sambiroto terletak tepat di sebelah timur Desa Pracimantoro. Desa Sambiroto dilewati jalan utama yang menghubungkan Provinsi Jawa Timur dengan DIY.

Desa Sambiroto memiliki obyek wisata yang sudah cukup berkembang berupa wisata air Sokanandi, pada gambar 11. Wisata air Sokanandi dibangun pada tahun 2016 dan memanfaatkan sumber air yang ada di Desa Sambiroto.

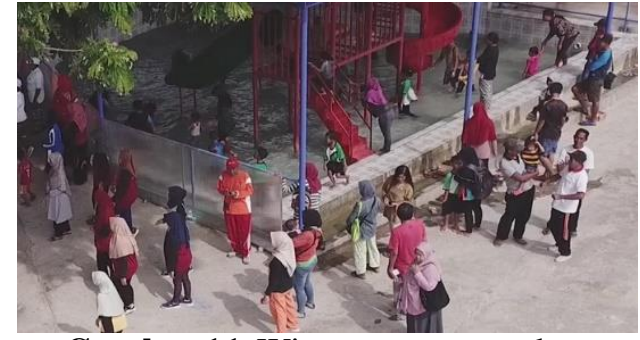

Gambar 11. Wisatawan yang sedang berwisata di objek wisata air Sokanandi Sumber: Kecamatan Pracimantoro

1. Desa Sedayu

Desa Sedayu adalah salah satu desa yang berada di utara ibukota Kecamatan Pracimantoro. Akses utama desa ini berupa jalan yang menghubungkan Kecamatan Pracimantoro dengan Kabupaten Wonogiri. Kata Sedayu berasal dari kata sido ayu yang berarti menjadi baik (Desa Sedayu, n.d.).

Desa yang terdiri dari 8 dusun ini memiliki sebuah embung yang bernama Embung Klepu pada gambar 12, dengan sumber air yang mengalir sepanjang tahun. Embung ini telah dimanfaatkan oleh masyarakat sebagai pengairan sawah dan sebagai tempat pemancingan. Embung ini dikelola oleh bumdes Sedayu Makmur sejak 2017.

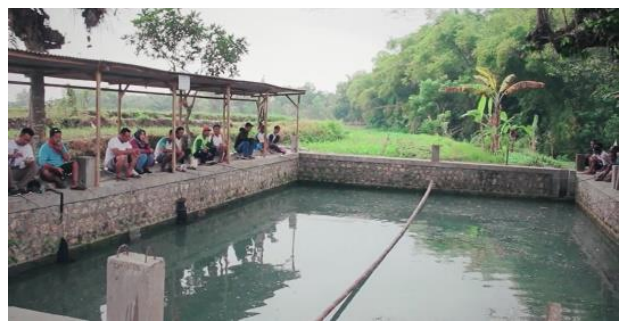

Gambar 12. Kegia tan memancing yang dilakukan oleh masyarakat di Embung Klepu Sumber: Kecamatan Pracimantoro

m. Desa Suci

Desa Suci berada di bagian timur Kecamatan Pracimantoro. Desa Suci dilewati jalan utama yang menghubungkan Provinsi Jawa Timur dengan DIY. Jalan tersebut menjadi akses utama keluar masuk Desa Suci.

Potensi yang ada di Desa Suci berupa lembah aliran Bengawan Solo purba. Desa ini menjadi salah satu pintu masuk untuk menelusuri Kawasan aliran Bengawan Solo Purba. 
Selain lembah Bengawan Solo purba, potensi lainnya adalah sentra kerajinan batik tulis, contoh batik pada gambar 13, lokasi di Dusun Ploso, Desa Suci. Hasil dari kerajinan batik tersebut didistribusikan ke daerah Pacitan, Jawa Timur.

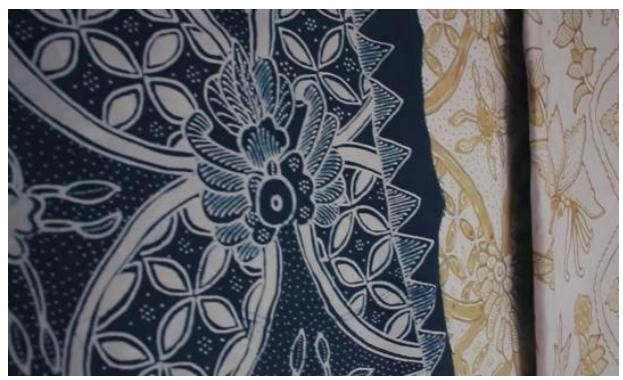

Gambar 13. Hasil Kerajinan Batik Tulis masyarakat Dusum Ploso, Desa Suci Sumber:Kecamatan Pracimantoro

n. Desa Sumberagung

Desa Sumberagung adalah desa yang terletak di bagian paling selatan Kecamatan Pracimantoro dan berbatasan langsung dengan Provinsi DIY. Desa ini dapat diakses melalui jalan utama yang menghubungkan Kecamatan Pracimantoro dan Kabupaten Wonogiri.

Desa Sumberagung memiliki situs geopark berupa Goa Seban dan lembah aliran Bengawan Solo purba. Goa Seban sendiri bagi sebagian masyarakat masih dianggap keramat dan sering digunakan untuk bertapa Selain situs geopark, Desa ini memiliki aset sejarah berupa Makam Ki Nerang Kusumo, Makam Ananta Kusumo dan Makam Sutokusumo (Hamdani, 2019).

Potensi lain yang ada di Desa Sumberagung berupa hasil kerajinan pirografi, seperti pada gambar 14 , dan makanan tradisional Setan Kober. Makanan setan kober sendiri merupakan camilan sejenis jenang yang terbuat dari talas, tepung ketan, kelapa, dan tepung beras (Arianto, 2018).

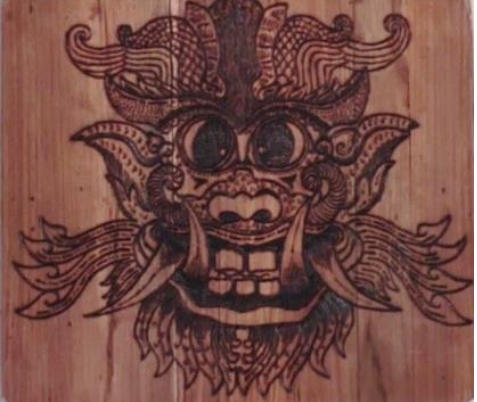

Gambar 14. Hasil Kerajinan Pirogra fi yang dibuat oleh masyarakat Desa Sumberagung Sumber: Kecamatan Pracimantoro

o. Desa Trukan

Desa Trukan berada di bagian utara Kecamatan Pracimantoro. Desa yang berjarak $4 \mathrm{Km}$ dari ibukota kecamatan ini terbagi menjadi 10 dusun. Desa Trukan memiliki luas 450,60 Ha dan menjadikan desa ini sebagai desa dengan luas paling kecil di Kecamatan Pracimantoro. Potensi yang ada di desa ini berupa embung dan pemancingan (Mustofa \& Nugroho, 2017).

p. Desa Tubokarto

Desa Tubokarto adalah desa yang terletak di bagian utara Kecamatan Pracimantoro. Akses desa ini berupa jalan utama yaitu Jalan Raya Pracimantoro-Wonogiri yang menghubungkan Kecamatan Pracimantoro dengan Kabupaten Wonogiri. Desa ini memiliki peninggalan sejarah berupa saluran air peninggalan jepang atau oleh masyarakat sekitar sering disebut "talang".

q. Desa Watangrejo

Desa Watangrejo terletak di selatan ibukota Kecamatan Pracimantoro dan berjarak $4 \mathrm{Km}$ dari ibukota kecamatan. Desa Watangrejo merupakan bagian dari Kawasan karst Gunung Sewu dan memiliki situs geopark berupa Goa Song Ireng (Prodjo, 2016).

r. Desa Wonodadi

Desa Wonodadi terletak di bagian barat laut Kecamatan Pracimantoro. Desa ini terdiri dari 8 dusun dengan jarak dari ibukota kecamatan sejauh $6 \mathrm{Km}$. Desa Wonodadi merupakan wilayah tertinggi di seluruh Kecamatan Pracimantoro.

Desa Wonodadi memiliki obyek wisata situs geopark berupa Goa Putri Kencana 
yang sudah cukup dikenal pada gambar 15. Selain itu, terdapat Kawasan Hutan Pinus Wonodadi yang berada di daerah perbukitan (Prakosa, 2018).

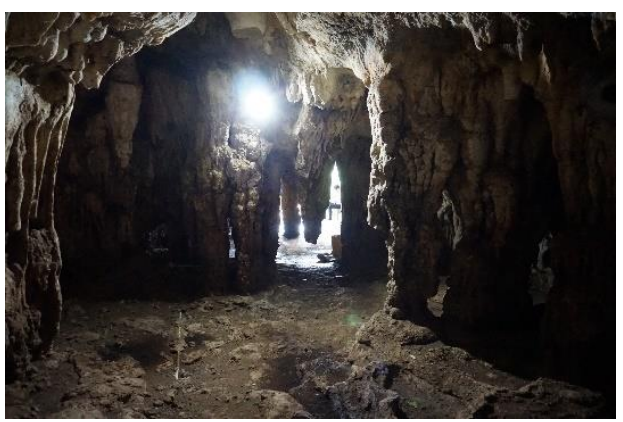

Gambar 15. Kondisiruangan yang a da di dalam Goa Putri Kencana

Berdasarkan kompilasi data yang ada, potensi yang ada di Kecamatan Pracimantoro dapat dikategorikan menjadi beberapa bagian, antara lain:

\section{a. Potensi Geopark}

Potensi Geopark yang ada di Kecamatan Pracimantoro tersebar di beberapa desa dengan konsentrasi terbanyak di Desa Gebangharjo. Potensi geopark ini antara lain:

1) Museum Karst di Desa Gebangharjo

2) Goa Mrico di Desa Gebangharjo

3) Goa Tembus di Desa Gebangharjo

4) Goa Sodong di Desa Gebangharjo

5) Goa Potro Bunder di Desa Gebangharjo

6) Goa Song Gilap di Desa Gebangharjo

7) Goa Luweng Sapen di Desa Gebangharjo

8) Goa Sonya Ruri di Desa Gebangharjo

9) Goa Sambi di Desa Glinggang

10)Goa Song Agung di Desa Glinggang

11)Goa Seban di Desa Sumberagung

12) Goa Song Ireng di Desa Tubokarto

13) Goa Putri Kencana di Desa Wonodadi

14) Lembah Aliran Bengawan Solo Purba di Desa Suci, Gambirmanis, Petirsari, dan Sumberagung

\section{b. Potensi Sejarah}

Potensi sejarah yang ada di Kecamatan Pracimantoro berada di desa Sumberagung dan Desa Tubokarto. Potensi sejarah di Desa Sumberagung berupa makam Ki Nerang Kusumo, Makam Ananta Kusumo dan Makam Sutokusumo. Sedangkan potensi di Desa Tubokarto berupa saluran air peninggalan Jepang.

c. Potensi Budaya

Potensi Budaya di Kecamatan Pracimantoro berupa kegiatan adat, makanan khas, dan hasil kerajinan, antara lain:

1) Pusat Kerajinan Blangkon di Desa Gebangharjo

2) Pura Puncak Jagad Spiritual di Desa Gebangharjo

3) Pusat Kerajinan Kayu di Desa Lebak

4) Kerajinan Pirografi di Desa Sumberagung

5) Kerajinan batik tulis di Desa Suci

6) Makanan khas berupa sate kambing, tongseng, dan sambal cabuk di Desa Pracimantoro

7) Makanan khas Setan Kober di Desa Sumberagung

d. Potensi Alam

Potensi alam yang ada didominasi oleh telaga atau embung yang dimanfaatkan oleh masyarakat untuk pengairan dan Sebagian dimanfaatkan untuk pariwisata ataupun masyarakat sekitar. Potensi alam tersebut antara lain:

1) Telaga Sebagor, Suruhan, dan Ndoyo di Desa Gambirmanis

2) Embung Gebangharjo di Desa Gebangharjo

3) Telaga Winong di Desa Gedong

4) Embung Pancuran Sari di Desa Jimbar

5) Telaga Kenanga di Desa Joho

6) Telaga Braholo di Desa Petirsari

7) Telaga Timbang di Desa Pracimantoro

8) Wisata air Sukanandi di Desa Sambiroto

9) Embung Sedayu di Desa Sedayu

10) Hutan Pinus Wonodadi di Desa Wonodadi

11) Pertanian dan pembibitan holtikultura di Desa Jimbar

Dari keempat kategori tersebut di atas, potensi Geopark merupakan potensi yang terbesar, bukan hanya karena keunikannya dibandingkan dengan tempat-tempat lain di sekitar Wonogiri, tetapi juga karena sudah memiliki status terdaftar sebagai Geopark di UNESCO. Status 
ini merupakan hal yang penting dalam pemasaran pariwisata.

Potensi terbesar kedua adalah potensi alam. Namun demikian dari semua daftar objek wisata yang ada yang terkait dengan alam, kebanyakan merupakan embung atau reservoir air. Mengingat daerah Pracimantoro memang biasanya mengalami kesulitan air pada bulanbulan tertentu, maka objek wisata air ini sebaiknya dikembangkan hanya dalam lingkup lokal untuk bisa tetap menjamin terpenuhinya kebutuhan air masyarakat kecamatan Pracimantoro. Alasan lain adalah karena biasanya skala dari embung ini tidak terlalu besar sehingga memang tidak mencukupi untuk menampung banyak pengunjung. Selain itu, kondisi alam daerah Pracimantoro juga kurang mendukung tersedianya air yang cukup sepanjang waktu pada embung tersebut. Hal ini membuat potensi wisata berupa embung ini menjadi kurang dapat diandalkan.

Potensi budaya dan sejarah memiliki kaitan yang sangat erat, karena itu dapat dikaitkan menjadi satu. Potensi adanya makam-makam yang memang selama ini sudah secara teratur selalu mendapatkan pengunjung berupa peziarah, memiliki potensi besar untuk dikembangkan dengan didukung kegiatankegiatan budaya. Sementara itu produk budaya berupa makanan dan kerajinan merupakan pendukung yang sangat penting dalam pariwisata.

Dari paparan di atas, dapat terlihat bahwa potensi wisata di kecamatan Pracimantoro yang paling kuat adalah Geopark, kemudian disusul dengan tema kultural. Wisata air lebih baik hanya diangkat untuk skala lokal karena tidak ada jaminan pasokan air yang cukup dan untuk menjamin kebutuhan air masyarakat tetap terpenuhi.

\section{KESIMPULAN}

Berdasarkan hasil kompilasi data dan pengelompokan potensi yang ada di Kecamatan Pracimantoro, Potensi yang paling dominan adalah Potensi Geopark yang tersebar di beberapa desa di Kecamatan Pracimantoro, yaitu Desa Gambirmanis, Desa Gebangharjo, Desa Petirsari, Desa Suci, Desa Sumberagung, Desa Watangrejo, dan Desa Wonodadi.. Potensi Geopark ini dapat dijadikan sebagai tema utama dalam pengembangan potensi wisata di Kecamatan Pracimantoro dikarenakan Geopark ini sudah diakui oleh UNESCO. Potensi sejarah dan budaya dapat menjadi tema kedua dari pengembangan pariwisata daerah kecamatan Pracimantoro. Sementara itu wisata alam terutama yang berupa reservoir air atau embung diharapkan untuk dikembangkan dalam skala lokal, sehingga hanya menjadi pendukung bagi wisata-wisata tema lainnya dalam pengembangan potensi wisata.

\section{UCAPAN TERIMAKASIH}

Penulis mengucapkan terimakasih kepada semua pihak yang terlibat dalam penelitian ini, terutama pihak-pihak dari Kecamatan Pracimantoro perangkat desa, dan masyarakat Kecamatan Pracimantoro atas dukungan yang telah diberikan kepada penulis sehingga dapat terselesaikannya penelitian ini. Penelitian ini juga tidak dapat berjalan tanpa pendanaan dari dana PNBP Universitas Sebelas Maret tahun anggaran 2020.

\section{REFERENSI}

Arianto, A. (2018, January 13). Setan Kober, Kuliner Unik dan Satu-satunya di Dunia. Joglosemarnews.

https://joglosemarnews.com/2018/01/seta n-kober-kuliner-unik-dan-satu-satunyadi-dunial

Badan Pusat Statistik Wonogiri. (2018). Kecamatan Pracimantoro Dalam Angka 2018. https://wonogirikab.bps.go.id

Badan Pusat Statistik Wonogiri. (2019). Kabupaten Wonogiri Dalam Angka 2019. https://wonogirikab.bps.go.id/publication /2019/08/16/c429e3c40206c5872200d54 4/kabupaten-wonogiri-dalam-angka2019.html.

Desa Jimbar. (n.d.). Sejarah Desa.

Desa Sedayu. (n.d.). Sejarah Desa.

Hamdani. (2019). Mau Tahu Daftar Nama Desa Dusun dan Potensi di Kecamatan Pracimantoro Wonogiri? Simak Penjelasan Lengkap Berikut Ini. Joglosemarnews. https://joglosemarnews.com/2019/10/ma u-tahu-daftar-nama-desa-dusun-danpotensi-di-kecamatan-pracimantorowonogiri-simak-penjelasan-lengkapberikut-ini/ 
Kabupaten Wonogiri. (2017). Ringkasan Eksekutif KAJIAN PENGEMBANGAN DESA WISATA DI KABUPATEN WONOGIRI.

https://www.ppid.wonogirikab.go.id/uplo ad/ppid/c428a913dbeb9f4f3213cbc942b3 9104_RINGKASAN EKSEKUTIF desa wisata 17.pdf

Kementrian Energi dan Sumber Daya Mineral. (n.d.). MUSEUM KARS INDONESIA. Retrieved October 29, 2020, from http://museum.geology.esdm.go.id/muse um-kars-indonesia

Mustofa, A., \& Nugroho, A. B. (2017). IDENTIFIKASI PENGEMBANGAN DESA WISATA DI KABUPATEN WONOGIRI. 6(3).

Parno. (2018). Gunung Sewu UNESCO Global Geopark. Badan Pengembangan dan Pembinaan Bahasa, Kementrian Pendidikan dan Kebudayaan.

Pertiwi, N. L. M. (2020, July 8). 5 Geopark Indonesia yang Masuk UNESCO Global Geopark. Kompas. https://travel.kompas.com/read/2020/07/0 8/181100427/5-geopark-indonesia-yangmasuk-unesco-global-geopark?page=all

Prakosa, D. E. (2018). Pesona Desa Inovasi.

Prasetya, A. W. (2018, November 18). Serunya Gowes Susur Lembah Bengawan Solo Purba. Kompas. https://travel.kompas.com/read/2018/11/2 0/070900727/serunya-gowes-susurlembah-bengawan-solo-purba

Prodjo, W. A. (2016, August). Mapala UI Telusuri Tiga Goa di Wonogiri Selama 112 Jam. Kompas.

UNESCO. (n.d.). What is a UNESCO Global Geopark? Retrieved October 22, 2020, from http://www.unesco.org/new/en/naturalsciences/environment/earthsciences/unesco-globalgeoparks/faq/what-is-a-unesco-globalgeopark/ 